\title{
Case Study: Consolidated Balance Sheet At Date Of Purchase
}

Peter Harris, New York Institute of Technology, USA

Petra Dilling, New York Institute of Technology, Canada

\begin{abstract}
Consolidated financial statements have gained great popularity over the last decade with the resurrection of acquisitions and the increased global expansion of business. This case study provides an actual case study of the preparation and presentation of a Consolidated Balance Sheet on the date of acquisition. An in-depth analysis is provided as to how to value the acquired entity, how to calculate Goodwill and how to measure the Non-Controlling interest portion. Work paper and adjusting entries are also highlighted to help facilitate the consolidation process.
\end{abstract}

Keywords: Consolidated Balance Sheet on the Date of Acquisition; Goodwill; Non-controlling Interest

\section{INTRODUCTION}

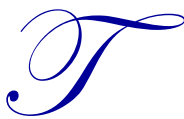

his case study will provide a thorough illustration as to the concepts of consolidations on the date of acquisition. On this date, an ensuing Consolidated Balance Sheet is created, whereby the acquiring and the acquired companies are combined as a single entity. Interestingly, there are options as to the consolidation basis which may be utilized, which also includes the push-down method of accounting. The pushdown method was illustrated in a previous case study and it is highly recommended that the reader resort to this, which can be found in Harris \& Dilling (2015).

An overview of this critical topic will be discussed, followed by a comprehensive illustration demonstrating the results of consolidated results as of the date of acquisition. Note that the resulting Balance Sheet will be the same with the push-down accounting result. This case study is recommended as a group project for an Advanced Accounting course as well as for a graduate Financial Statement Analysis class.

\section{FACTS}

On December 31, 2011, PA. Inc. purchased 95 percent of Sub. Inc. for 120,000 cash. The Balance Sheet of each corporation just prior to the acquisition is presented below. Additionally, book value and fair value for all of Sub's assets and liabilities are equal, with the exception of Property, Plant and Equipment, whose fair value is 47,000.

Table 1. Balance sheet before acquisition

\begin{tabular}{|c|c|c|}
\hline \multicolumn{3}{|l|}{ Balance Sheet } \\
\hline & PA Inc. & SUB Inc. \\
\hline Assets & $12 / 31 / 2011$ & $12 / 31 / 2011$ \\
\hline \multicolumn{3}{|l|}{ Current Assets } \\
\hline Cash & $\$ 170,000$ & $\$ 21,000$ \\
\hline Accounts receivable (Net) & 60,000 & 45,000 \\
\hline Inventory & 50,000 & 45,000 \\
\hline Total Current Assests & $\$ 280,000$ & $\$ 111,000$ \\
\hline \multicolumn{3}{|l|}{ Fixed Assets } \\
\hline Property, Plant, and Equipment (Net of Accumulated Depreciation) & 265,000 & 42,000 \\
\hline Goodwill & & \\
\hline Total Assets & 545,000 & 153,000 \\
\hline
\end{tabular}

(Table 1 continued next page) 
(Table 1 continued)

\begin{tabular}{|c|c|c|}
\hline & PA Inc. & SUB Inc. \\
\hline \multicolumn{3}{|l|}{ Liabilities } \\
\hline \multicolumn{3}{|l|}{ Current Liabilities } \\
\hline Accounts Payable & $\$ 70,000$ & $\$ 30,000$ \\
\hline Accruals Payable & 20,000 & 15,000 \\
\hline Total Current Liabilities & $\$ 90,000$ & $\$ 45,000$ \\
\hline \multicolumn{3}{|l|}{ Non-Current Liabilities } \\
\hline Bonds Payable & $\$ 180,000$ & \\
\hline Total liabilities & $\$ 270,000$ & $\$ 45,000$ \\
\hline \multicolumn{3}{|l|}{ Shareholders' Equity } \\
\hline Non-Controlling Interest (Share of Subsidiary) & $\$$ & $\$$ \\
\hline Common Stock ( $\$ 5$ Par) & 100,000 & 55,000 \\
\hline Paid In Capital & 20,000 & 8,000 \\
\hline Retained Earnings & 155,000 & 45,000 \\
\hline Total Shareholders' Equity & $\$ 275,000$ & $\$ 108,000$ \\
\hline Total Liabilities and Shareholder's Equity & $\$ 545,000$ & $\$ 153,000$ \\
\hline
\end{tabular}

\section{REQUIRED}

1. Recording the purchase of Sub. Inc. by PA (the parent company).

2. What is the implied fair value of Sub Inc.?

3. Calculate the amount of Goodwill implicit in this purchase.

4. What is the amount of the non-controlling interest share in Sub Inc. at the date of acquisition?

5. What is the consolidated depreciation expense to be reflected in the consolidated Income Statement for 2012 assuming a 10 year depreciation life for property, plant and equipment?

6. Prepare the necessary work paper adjusting entries on the date of purchase.

7. Prepare a consolidated Balance Sheet immediately after this acquisition on 12/31/2011.

\section{RECOMMENDED SOLUTIONS}

\section{Record the purchase of Sun Inc. by PA (the parent company). \\ Dr. Investment in Sub $\quad 120,000$

Cr. Cash $\quad 120,000$

This transaction brings the cash balance in PA down to $\$ 50,000$.

2. What is the implied fair value of Sub Inc.?

This will equal the price paid for SUB. Inc. divided by the ownership share acquired by PA. Inc.

The implied fair value of Sub. Inc. is $\$ 120,000$ divided by 95 percent, which equals $\$ 126,316$.

\section{Calculate the amount of Goodwill implicit in this purchase.}

Goodwill will equal the excess value of the company's net identifiable net assets. In this situation, the value of Sub Inc. is the purchase amount paid by PA divided by the share of ownership interest, calculated as follows; 120,000 /.95=126,316. The identifiable net assets of Sub Inc., are its Shareholders' Equity book value, plus or minus fair value adjustments. In this case, the only fair value adjustment is an increase in Property, plant and equipment by $\$ 5,000(47,000-42,000)$, making the fair value of Bub's identifiable net assets equal to: $\$ 108,000$ plus 5,000 , or $\$ 113,000$. Goodwill will thus equal: $\$ 126,316$ less 113,000 , or $\$ 13,316$. 
4. What is the amount of non-controlling interest share in Sub Inc. at the date of acquisition? This will equal the implied value of Sub. Inc. times the non-controlling ownership of Sun. Inc.

This will equal $\$ 126,316$ times 5 percent, or $\$ 6,316$.

5. What is the consolidated depreciation expense to be reflected in the consolidated Income Statement for 2012 assuming a 10 year depreciation life for property, plant and equipment?

The consolidated value of Property, Plant and Equipment as of the date of purchase on 12/31/2011 will be: $\$ 265,000$ plus $\$ 47,000$ ( 42,000 plus 5,000 above), or $\$ 312,000$. This amount divided by 10 years using the straight line depreciation method will yield a depreciation expense total for 2012 in the amount of $\$ 31,200$.

6. Prepare the necessary work paper adjusting entries on the date of purchase.

The consolidated worksheet elimination entries are as follows:

Dr. Common Stock-Sub $\quad 55,000$

Dr. Paid In Capital -Sub $\quad 8,000$

Dr. Retained Earnings-Sub $\quad 45,000$

Dr. Property, Plant and Equipment $\quad 5,000$

Dr. Goodwill $\quad 13,316$

Cr. Investment in Sub $\quad 120,000$

Cr. Non-controlling Interest in Sub $\quad 6,316$

(126,316 times 5 percent)

7. Prepare a Consolidate Balance Sheet at the date of purchase on 12/31/2011.

Table 2. Consolidated balance sheet

\begin{tabular}{|c|c|c|c|c|c|}
\hline \multirow{2}{*}{$\begin{array}{r}\text { Assets } \\
\text { Current Assets }\end{array}$} & \multirow[t]{2}{*}{ PA INC. } & \multirow[t]{2}{*}{ SUB INC. } & \multicolumn{2}{|c|}{ Adjustments } & \multirow[t]{2}{*}{ Consolidate } \\
\hline & & & Dr. & Cr. & \\
\hline Cash $=\$ 191,000-120,000=$ & $\$ 50,000$ & $\$ 21,000$ & & & $\$ 71,000$ \\
\hline Accounts Receivable (Net) & 60,000 & 45,000 & & & 105,000 \\
\hline Inventory & $\underline{50,000}$ & 45,000 & & & 95,000 \\
\hline Total Current Assets & $\overline{160,000}$ & $\overline{111,000}$ & & & $2 \overline{71,000}$ \\
\hline Investment in Sub. Inc. & 120,000 & & & 120,000 & \\
\hline \multicolumn{6}{|l|}{ Fixed Assets } \\
\hline $\begin{array}{l}\text { Property, Plant, and Equip. } \\
\text { (Net) }\end{array}$ & 265,000 & 42,000 & 5,000 & & 312,000 \\
\hline Goodwill & & & 13,316 & & 13,316 \\
\hline Total Assets & 545,000 & 153,000 & 18,316 & 120,000 & 596,316 \\
\hline \multicolumn{6}{|l|}{ Liabilities } \\
\hline \multicolumn{6}{|l|}{ Current Liabilities } \\
\hline Accounts Payable & $\$ 70,000$ & $\$ 30,000$ & & & $\$ 100,000$ \\
\hline Accruals Payable & $\underline{20,000}$ & $\underline{15,000}$ & & & $\underline{35,000}$ \\
\hline Total Current Liabilities & $\overline{90,000}$ & $\overline{45,000}$ & & & $13 \overline{13,000}$ \\
\hline \multicolumn{6}{|l|}{ Non-Current Liabilities } \\
\hline Bonds Payable & 180,000 & & & & 180,000 \\
\hline Total liabilities & 270,000 & 45,000 & & & 315,000 \\
\hline \multicolumn{6}{|l|}{ Shareholders' Equity } \\
\hline Non-Controlling Interest & & & & $\$ 6,316$ & $\$ 6,316$ \\
\hline Common Stock ( $\$ 5$ Par) & 100,000 & 55,000 & 55,000 & & 100,000 \\
\hline Paid In Capital & 20,000 & 8,000 & 8,000 & & 20,000 \\
\hline Retained Earnings & 155,000 & 45,000 & 45,000 & & 155,000 \\
\hline Total Shareholders' Equity & 275,000 & $\mathbf{1 0 8 , 0 0 0}$ & 108,000 & 6,316 & 281,316 \\
\hline $\begin{array}{l}\text { Total Liabilities and } \\
\text { Shareholder's Equity }\end{array}$ & 545,000 & 153,000 & 126,316 & 126,316 & 596,316 \\
\hline
\end{tabular}

Copyright by author(s); $\underline{\mathrm{CC}-\mathrm{BY}}$ 
PA Inc. And SUB Inc. Balance Sheet

\begin{tabular}{|c|c|}
\hline & 12/31/2011 \\
\hline \multicolumn{2}{|l|}{ Assets } \\
\hline \multicolumn{2}{|l|}{ Current Assets } \\
\hline Cash & $\$ 71,000$ \\
\hline Accounts Receivable (Net) & 105,000 \\
\hline Inventory & 95,000 \\
\hline Total Current Assets & 271,000 \\
\hline \multicolumn{2}{|l|}{ Fixed Assets } \\
\hline Property, Plant, and Equipment (Net of Accumulated Depreciation) & 312,000 \\
\hline Goodwill & 13,316 \\
\hline Total Assets & 596,316 \\
\hline \multicolumn{2}{|l|}{ Liabilities } \\
\hline \multicolumn{2}{|l|}{ Current Liabilities } \\
\hline Accounts Payable & 100,000 \\
\hline Accruals Payable & 35,000 \\
\hline Total Current Liabilities & 135,000 \\
\hline \multicolumn{2}{|l|}{ Non-Current Liabilities } \\
\hline Bonds Payable & 180,000 \\
\hline Total liabilities & 315,000 \\
\hline \multicolumn{2}{|l|}{ Shareholders' Equity } \\
\hline Non-Controlling Interest (Share of Subsidiary) & 6,316 \\
\hline Common Stock (\$5 Par) & 100,000 \\
\hline Paid In Capital & 20,000 \\
\hline Retained Earnings & 155,000 \\
\hline Total Shareholders' Equity & 281,316 \\
\hline Total Liabilities and Shareholder's Equity & 596,316 \\
\hline
\end{tabular}

\section{CONCLUSION}

This case study introduced the student to the concepts of consolidated financial statements on the date of acquisition. A comprehensive illustration was provided, resulting in a Balance Sheet presentation of a consolidated group. Compliant journal entries necessary to record the purchase of the subsidiary, as well as the consolidated worksheet elimination entries were provided towards the presentation of the Balance Sheets. A follow up case study on a full set of financial statements; including a Balance Sheet, Income Statement and Cash Flow Statement subsequent to the acquisition date is highly recommended. Additionally, a case study illustrating the effects of consolidation after the date of acquisition where the push-down accounting method is utilized should also be presented.

\section{AUTHOR BIOGRAPHIES}

Peter Harris is a Professor and Chair of the Accounting and Finance department at the New York Institute of Technology. Previously, he has worked for Ernst and Young LLP. He is an author of over 60 refereed journal articles and over 150 intellectual contributions. He can be reached at pharris@nyit.edu (corresponding author).

Dr. Petra Dilling, CPA, CGA, is an Associate Dean, School of Management, at the New York Institute of Technology in Vancouver. Her areas of expertise are in financial and sustainability (CSR) reporting.

\section{REFERENCES}

Harris, P. \& Dilling, P. (2015 forthcoming). Push-down Accounting: A Comprehensive Case Study, Journal of Business Case Studies. 